ロ絵 1 : 伊江島南岸のビーチロックとニャティヤガマ洞窟床堆積物の較正年代

\title{
Pictorial 1 : Calibrated Ages of Beachrock Samples and Consolidated Deposits of Nyateya-gama, Southern Coast of Ie Island, Okinawa
}

伊江島南岸において, ビーチロックとニャティヤガマ洞窟床の堆積物から 27 試料を採取し, ${ }^{14} \mathrm{C}$ 年代測定を行い較正年代 をもとめた。これらの年代は伊江島の環境変遷史を考察する上で重要な資料である (本文 p . 665-674 参照).

A total of 27 fossil shells, corals and calcarenite samples were collected from the southern coast of Ie Island to determine their accumulation ages and formation of beachrock. The calibrated ages may contribute to the late Holocene geochronology of Ie Island (see text p. 665-674).

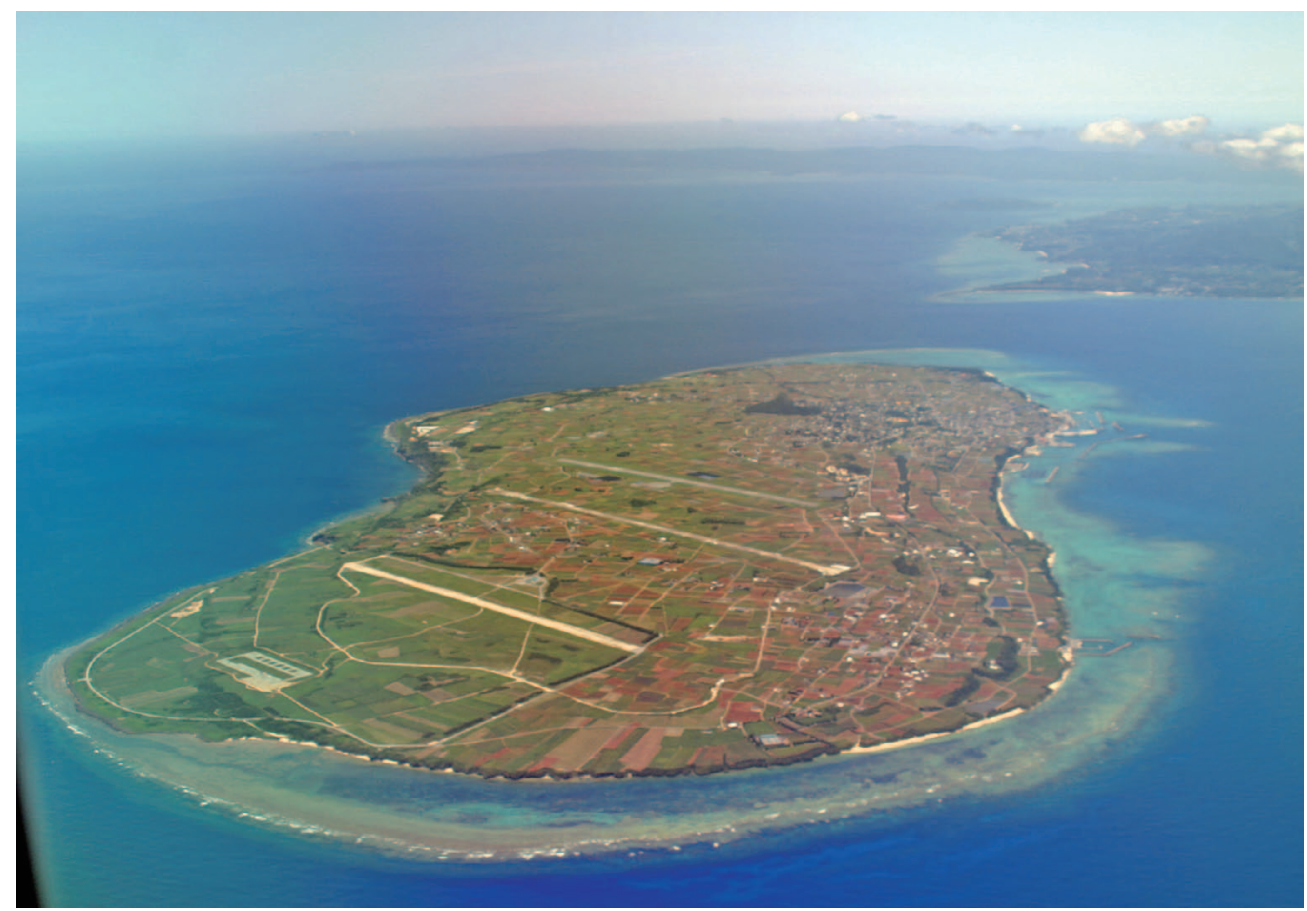

図 1 隆起サンゴの伊江島を南西上空から撮影した斜め写真. 3 本の直線は滑走路（跡）で, その東部 (上部) の黒い突出部 は海抜 $172 \mathrm{~m}$ の城山.

Fig. 1 Oblique aerial photograph shows uplifted coral reef of Ie Island. The photograph was taken from the southwest off the island. The three straight lines are runways, and the black colored rise to the east is Mt. Gusuku (172 m a.s.l.).

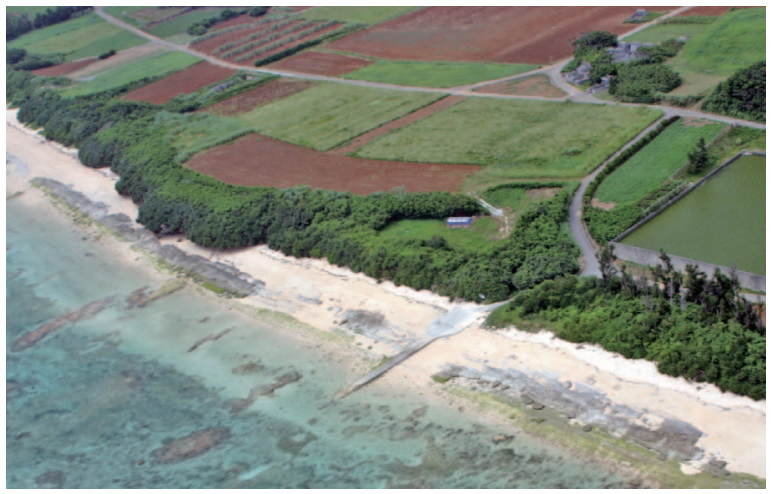

図 2 伊江島南西, シューベのビーチロックの斜め写真. ビー チロック（灰色および黄緑色）は，汀線と平行に約 $300 \mathrm{~m}$ にわたり断続的に発達している.

Fig. 2 Oblique aerial photograph of beachrocks developed along Syuhbe beach, southwest coast of Ie Island. Grey and light-green colored beachrocks run parallel to the strandline about $300 \mathrm{~m}$ in length and $10 \mathrm{~m}$ in width with a discontinuity.

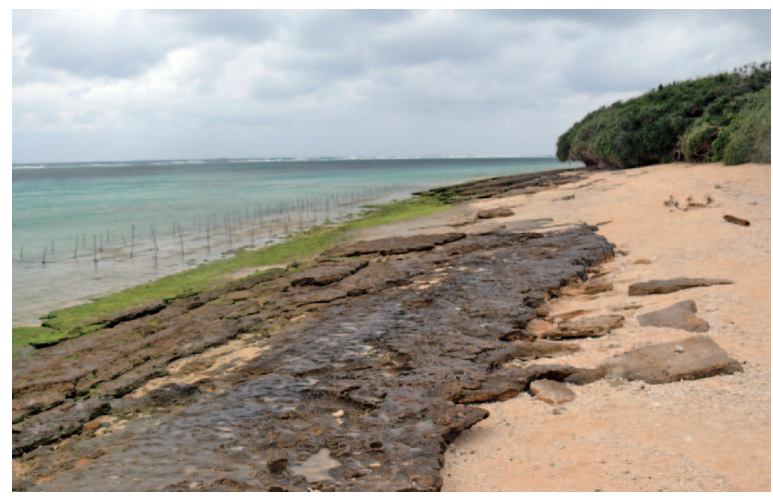

図 3 シューベのビーチロックの地上写真. ビーチロックか ら採取した石灰質砂岩から 1,364 cal BP（NU-1360） の年代が得られた.

Fig. 3 The photograph shows beachrock developed on Shuhbe beach. A calcarenite sample (NU-1360) collected from the beachrock was aged to 1,364 cal BP. 
ロ絵 1 (つづき) : 伊江島南岸のビーチロックとニャティヤガマ洞窟床堆積物の較正年代

Pictorial 1 : Calibrated Ages of Beachrock Samples and Consolidated Deposits of Nyateya-gama, Southern Coast of Ie Island, Okinawa

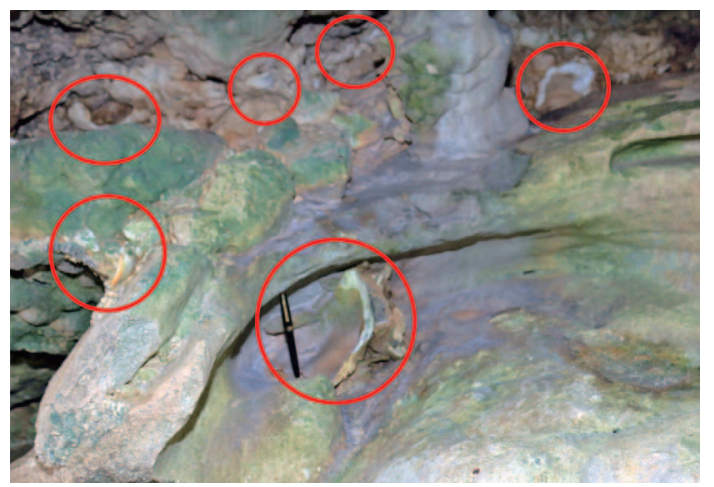

図 4 ニャティヤガマ洞窟西洞入り口付近のシャコ貝化石 (赤丸). 右上のシャコ貝の年代は $2,271 \mathrm{cal} \mathrm{BP}(\mathrm{NU}-$ 1069) であった. ボールペンの長さは $13.5 \mathrm{~cm}$.

Fig. 4 Red circles indicate fossils of Tridacna squamosa observed at the west entrance of Nyateya-gama cave. Upper right shell sample was aged to $2,271 \mathrm{cal} \mathrm{BP}$ (NU-1069). The length of the ballpoint pen is $13.5 \mathrm{~cm}$.

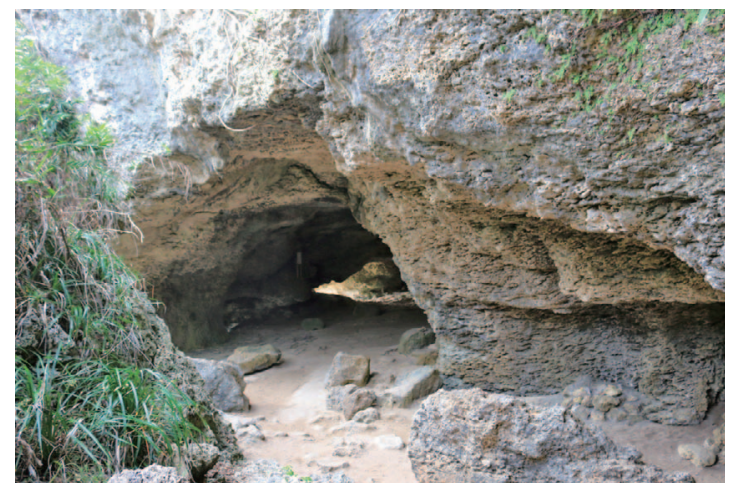

図 6 ニャティヤガマ洞窟東洞入り口. 入り口の高さは約 $5 \mathrm{~m}$.

Fig. 6 East entrance of Nyateya-gama cave whose height is ca. $5 \mathrm{~m}$.

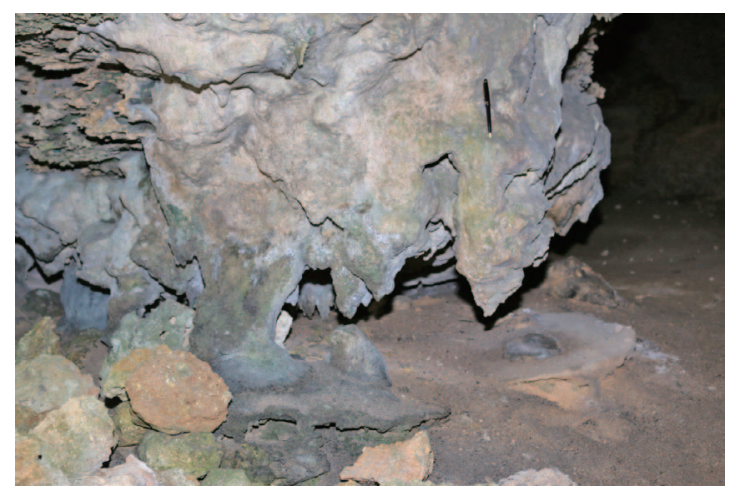

図 8 ニャティヤガマ洞窟東洞入り口で観察された鍾乳石 (長さ約 $50 \mathrm{~cm}$ ).

Fig. 8 Stalactites (ca. $50 \mathrm{~cm}$ long) were observed at east entrance of Nyateya-gama cave.

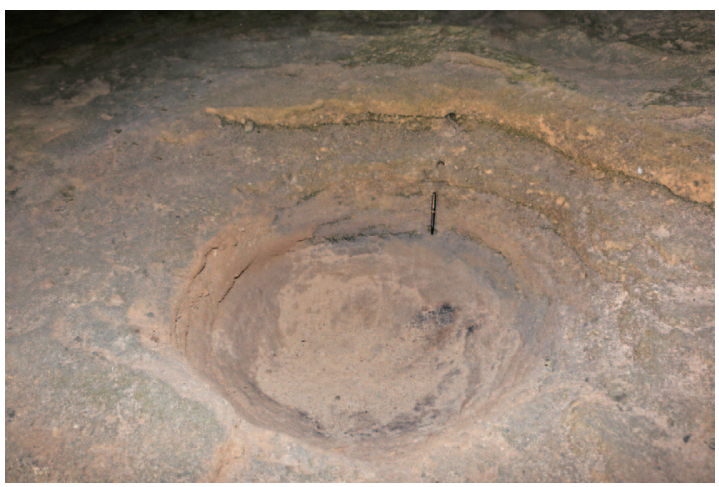

図 5 ニャティヤガマ洞窟西洞入り口付近の石灰質砂岩の 断面とポットホール $(90 \times 90 \mathrm{~cm})$.

Fig. 5 The photograph shows a cross-section of consolidated deposits (upper part) and a pothole $(90 \times$ $90 \mathrm{~cm}$ wide and ca. $50 \mathrm{~cm}$ deep) observed at the west entrance of Nyateya-gama cave.

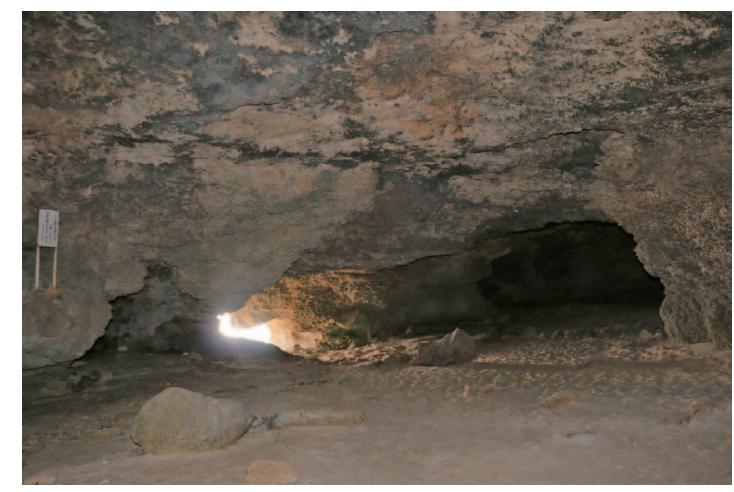

図 7 ニャティヤガマ洞窟東洞からみた西洞入り口.

Fig. 7 West entrance of Nyateya-gama cave, viewed from east entrance.

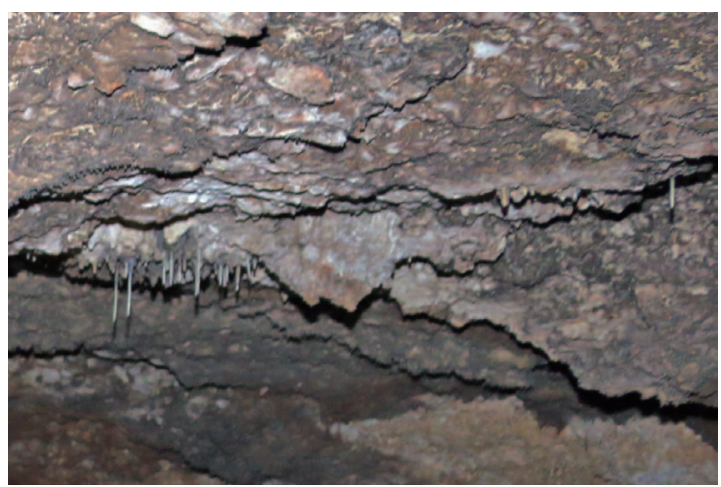

図 9 ニャティヤガマ洞窟西洞天井のストロー（約 6 〜 $10 \mathrm{~cm}$ ) と鍾乳石.

Fig. 9 The photograph shows straws (ca. 6-10 cm long) and stalactites suspended from the ceiling of west Nyateya-gama cave. 